\title{
CONCEPTUALIZATION OF CULTURAL INTELLIGENCE, INTERCULTURAL SENSITIVITY, INTERCULTURAL COMPETENCE, AND NOMOLOGICAL NETWORK: a contact hypothesis study of sociology of education ${ }^{1}$
}

\author{
Ashraf Alam \\ University of Delhi \\ South Moti Bagh, New Delhi, India
}

DOI: https://doi.org/10.22409/mov.v7i15.45814

\begin{abstract}
This paper presents a qualitative research examining the extent to which sojourns abroad engage their partakers in intercultural interactions and explores whether experiences like this translates into intercultural growth in students. The results of this study demonstrated that studying abroad would not suffice for complete immersion into the local community or allow one to discover the nuances of another culture in their entirety. Nonetheless, students who were surrounded by their local and international counterparts were exposed to foreign cultures and were motivated to explore and interpret the diversity they encountered. They were thus equipped with knowledge of unfamiliar cultures and were sensitised to cultural diversity. Such contact often challenged the students' established opinions and ideas, which largely stemmed from stereotypes about specific cultures. Rethinking this, to varied extents, resulted in evolved attitudes and values. International engagement also stimulated introspection and a deepened understanding of identity among the students, thereby contributing to their self-awareness. By offering opportunities to experience cultural diversity, the sojourn prompts students to develop coping strategies and draw parallels with their own culture, along with fostering intercultural development to a certain degree, and is therefore of great significance for policy makers, curriculum developers, teachers and tertiary students.
\end{abstract}

Key-words: Contact Hypothesis. Intercultural Sensitivity. Intercultural Competence. Study Abroad.

\footnotetext{
${ }^{1}$ I would like to offer my most sincere thanks and appreciation to the participants of this study for their faith in my research, for it was their cooperation and understanding that made it possible. I would also like to express my deep gratitude to the anonymous reviewers for their helpful comments, feedback, and suggestions on the initial drafts of the manuscript.
} 


\title{
movim nto \\ revista de educação do \\ programa de pós-graduação \\ faculdade de educação \\ ano 7 - número 15 - 2020
}

\section{CONCEPTUALIZACION DE INTELIGENCIA CULTURAL, SENSIBILIDAD INTERCULTURAL, COMPETENCIA INTERCULTURAL Y ROJO NOMOLOGO:}

un estudio de hipótesis de contacto de sociología de la educación

\begin{abstract}
RESUMEN
Este trabajo presenta una investigación cualitativa que examina hasta qué punto las estancias en el extranjero involucran a sus partícipes en las interacciones interculturales y explora si experiencias como esta se traducen en un crecimiento intercultural en los estudiantes. Los resultados de este estudio demostraron que estudiar en el extranjero no sería suficiente para una inmersión completa en la comunidad local ni permitir que uno descubra los matices de otra cultura en su totalidad. Sin embargo, los estudiantes que estaban rodeados de sus homólogos locales e internacionales estaban expuestos a culturas extranjeras y estaban motivados para explorar e interpretar la diversidad que encontró. Por lo tanto, estaban equipados con conocimientos de culturas desconocidas y estaban sensibilizados a la diversidad cultural. Tal contacto a menudo desafió las opiniones e ideas establecidas por los estudiantes, que en gran medida provenían de estereotipos sobre culturas específicas. Repensar esto, en una extensión variada, dio lugar a actitudes y valores evolucionados. El compromiso internacional también estimuló la introspección y una comprensión más profunda de la identidad entre los estudiantes, contribuyendo así a su autoconciencia. Al ofrecer oportunidades para experimentar la diversidad cultural, la estadía lleva a los estudiantes a desarrollar estrategias de afrontamiento y trazar paralelismos con su propia cultura, junto con el fomento del desarrollo intercultural hasta cierto punto, y por lo tanto es de gran importancia para los responsables de la formulación de políticas, los desarrolladores de planes de estudio, los profesores y los estudiantes terciarios.

Palabras clave: Hipótesis de contacto. Sensibilidad Intercultural. Competencia Intercultural. Estudiar en el extranjero.
\end{abstract}

\section{CONCEITUAÇÃO DE INTELIGÊNCIA CULTURAL, SENSIBILIDADE INTERCULTURAL, COMPETÊNCIA INTERCULTURAL E REDE NOMOLÓGICA: \\ um estudo de hipóteses de contato da sociologia da educação}

\section{RESUMO}

Este artigo apresenta uma pesquisa qualitativa que examina até que ponto as estadas no exterior envolvem seus participantes em interações interculturais e explora se experiências como essa se traduzem em crescimento intercultural dos alunos. Os resultados deste estudo demonstraram que estudar no exterior não seria suficiente para uma imersão completa na comunidade local ou permitir que alguém descubra as nuances de outra cultura em sua totalidade. No entanto, os alunos que 


\section{movim nto \\ revista de educação do \\ programa de pós-graduação \\ faculdade de educação \\ ano 7 - número 15 - 2020}

estavam cercados por seus colegas locais e internacionais foram expostos a culturas estrangeiras e foram motivados a explorar e interpretar a diversidade que encontraram. Eles foram, portanto, equipados com o conhecimento de culturas desconhecidas e foram sensibilizados para a diversidade cultural. Esse contato muitas vezes desafiou as opiniões e ideias estabelecidas dos alunos, que se originaram em grande parte de estereótipos sobre culturas específicas. Repensar isso, em graus variados, resultou em atitudes e valores evoluídos. O envolvimento internacional também estimulou a introspecção e uma compreensão aprofundada da identidade entre os alunos, contribuindo assim para sua autoconsciência. Ao oferecer oportunidades de vivenciar a diversidade cultural, a permanência estimula os alunos a desenvolver estratégias de enfrentamento e traçar paralelos com sua própria cultura, junto com a promoção do desenvolvimento intercultural até certo grau e, portanto, é de grande importância para formuladores de políticas, desenvolvedores de currículo, professores e alunos do ensino superior.

Palavras-chave: Hipótese de Contato. Sensibilidade Intercultural. Competência Intercultural. Estudo no Exterior.

\section{Introduction}

Short-term study abroad programmes are becoming increasingly widespread amongst the Asian populace, including Indian students. This creates cross-cultural opportunities for those involved (ALADIA, 2017). Through these programs, students may spend a semester or year abroad to broaden their conceptual and subjectspecific knowledge while simultaneously learning about the host country, its culture and its people and developing foreign language proficiency (ANG; VAN DYNE, 2015). Additionally, students will have many opportunities to immerse themselves into intercultural collaborations in class and further interact with their international peers, communicate with individuals of diverse cultures and understand their identities outside the classroom (ARASARATNAM-SMITH, 2017).

Student mobility appears to be an excellent opportunity for students to engage with a variety of cultures, negotiate meaning, make sense of new realities and perhaps even reinvent themselves (ARMFIELD, 2004). Intercultural experience gained through study abroad programs helps students to heighten their observations skills, increases their tolerance for ambiguity and uncertainty (Aveni, 2005). Students further learn to adapt to new cultural contexts i.e. they become better equipped to grasp, reason and behave appropriately in situations characterised by cultural diversity (BARKIN, 2018). It must be noted that the above- 


\section{movim nto \\ revista de educaçāo do \\ programa de pós-graduação \\ faculdade de educação \\ ano 7 - número 15 - 2020}

mentioned outcomes are highly subjective and depend on a variety of outcomes, principally on whether the student themselves recognises and appreciates the opportunity for direct and meaningful participation and engagement (BENNETT, 1986).

This article will present empirical research investigating whether and to what extent study abroad experiences cultivate students' intercultural development i.e. whether and to what extent it helps them acquire the ability to interact effectively with people of cultures other than one's own. In other words, the authors will attempt to examine whether sojourns abroad affect students' intercultural knowledge and awareness of the different values and behaviours that people from other cultures and social groups hold. Moreover, attitudes toward otherness and tolerance for cultural difference and outgroups in general will also be explored.

In consideration of the rapid globalisation in all spheres of life and the increased internationalisation of tertiary level education, exposure to diverse cultures appears to be inevitable for the youth (BENNETT, 2017). Consequently, students' growth in intercultural competence is an integral prerequisite to prepare them to study in unfamiliar settings and engage with people from other cultural backgrounds, to attend sessions with faculty from different cultures, to communicate with foreigners whilst travelling, and ultimately, work with a culturally diverse workforce in a range of international workplaces (BENSON; JOSEPH; MOORE, 2017). Since empirical research carried out in the Asian context does not unanimously confirm a positive impact of the sojourn on an individual's intercultural growth, the current study seeks to provide more data on the experience of international students and thus seems timely.

\section{Literature review}

Extensive research into students' experiences with mobility has been undertaken by many. This has had various outcomes including increased language proficiency, reduced ethnocentrism, awareness of other cultures and one's own, and growth in intercultural communication skills and professional competence (BIANCO, 


\section{movim nto \\ revista de educaçāo do \\ programa de pós-graduação \\ faculdade de educação \\ ano 7 - número 15 - 2020}

2009). Results concerning the impact of studying abroad on students' intercultural competence, however, are often conflicting (BLASCO; GUSTAFSSON, 2004).

While some researchers are convinced that optimal intercultural learning stems from direct contacts, others claim that the results of student mobility are highly variable, and students may return home more ethnocentric and reluctant to interact with people who come from different linguistic and cultural environments. It is worth noting that there is empirical research supporting the claim that an increase in intercultural sensitivity can be achieved through education and training without staying abroad (BREMER; ROBERTS; VASSEUR; SIMNOT; BROEDER, 2014).

$A$ few researchers maintain that an individual can witness an event without ever experiencing it (BREWER; CUNNINGHAM, 2010). It has been evidenced that intercultural contact does not directly change attitudes, and rather it is the mediation of the perceived importance of the contact experience that contributes to the change (BURROW, 2019). A plethora of studies have, however, have attempted to support the notion that study abroad programs have a positive impact on students in terms of intercultural competence. Researchers found that sojourns did show significant improvement in the participants' intercultural sensitivity (CASPI, 1984). In a similar vein, students investigated by a research demonstrated growth in intercultural sensitivity following one or two semesters of studying abroad (CHIEFFO, 2010). Additionally, the gain in intercultural sensitivity was higher in the latter group as opposed to the former.

Another research demonstrated that student sojourners exhibited an increase in knowledge that was culturally-specific, and the greatest growth was noticed in knowledge themes of culture, history, daily life, food and drink, and values and politics (COTS; AGUILAR; MAS-ALCOLEA; LLANES, 2016). Since it had been claimed by a researcher that intercultural knowledge is a basic component requisite for intercultural skills and attitudes, the researchers concluded that studying abroad positively impacts the development of intercultural competence (CRISP, TURNER, 2012).

A researcher reported that short term stays for studying abroad contributed to change in both attitudes and behaviours in students, leading to the better 


\section{movimento \\ revista de educação do \\ programa de pós-graduação \\ faculdade de educação \\ ano 7 - número 15 - 2020}

understanding of other people and cultures, more openness to diversity and the development of a more inclusive mindset (CUBILLOS; ILVENTO, 2018). Likewise, another researcher provided compelling evidence that student mobility results in attitudinal changes about Asia (CUSHNER, 2010).

The study carried out by the authors and discussed in the subsequent parts of this paper assumes that intercultural communicative competence (ICC), the ability to communicate effectively and appropriately in intercultural situations based on one's intercultural knowledge, skills, and attitudes, is developmental in nature i.e., it is a lifelong process with no final stage. ICC shifts over time, increases with experiences in intercultural contacts and is context driven - contextual variables influence its development.

Another theoretical foundation underlying the study is Bennett's (1993) developmental model of intercultural sensitivity (DMIS) describing individuals' reactions to intercultural differences on a continuum ranging from ethnocentric to ethno-relative stages (DEARDORFF, 2018). As for a context-based perspective on ICC, (S TING-TOOMEY, 1999) model has been adopted. The researcher assumes that the process of ICC development does not occur in a vacuum but only through interactions with and in relation to persons from diverse backgrounds (DERVIN; DU; HÄRKÖNEN, 2018). Thus, what is a requisite for its growth is reflection and mindfulness; it is through the critical analysis of experiences that individuals become aware of how they are intentionally developing specific aspects of ICC (DOERR; TAÏEB, 2017).

Another theoretical framework the paper applies is contact theory, or the contact hypothesis (ALLPORT; CLARK; PETTIGREW, 1954), which provides a means of understanding and designing programs aimed at improving intergroup relations. According to the intergroup contact hypothesis, bringing people from diverse linguistic and cultural backgrounds together does not naturally result in a sense of cultural tolerance and acceptance of others, nor does it make them engaged with "out-group" members, open-minded and non-prejudiced toward them (EGEKVIST; LYNGDORF; DU; SHI, 2016). For direct interactions with foreigners to translate into enhanced ICC, certain conditions have to be met (ENNIS; RILEY, 


\section{movim nto \\ revista de educaçāo do \\ programa de pós-graduação \\ faculdade de educação \\ ano 7 - número 15 - 2020}

2018). These include common goals, equal group status within the situation, intergroup cooperation, and authority or community support (FONG, 2020). A range of studies proved that the favourable circumstances outlined by Allport i.e. meaningful international and intergroup contact, might have positive effects on intercultural attitudes and reduce intergroup bias, causing individuals to recategorize themselves as a single group ("we") rather than as two separate groups ("us" and "them") (FORBES, 1997).

Recent research in community psychology has suggested a potential use of the contact theory as a tool for building intercultural relationships. The contact hypothesis helped conceptualize international students' study abroad programs as linked with changes in their attitudes and identities because several of the contact hypothesis conditions are congruent with international students' organizational values (FOSTER, 2011). Equal status is provided by recommending participatory learning at host universities, i.e., by engaging students in collaborative projects. In addition to this, equal status is strengthened by the fact that international student participants are similar in terms of their age and the various activities they may be involved in (FREED, 1995). The students have common goals i.e. they wish to graduate and build a range of other meaningful relationships during the sojourn, and thus seeking mutual understanding of human diversity is crucial for them (GAERTNER; RUST; DOVIDIO; BACHMAN, 1996). As for intergroup cooperation, it may be offered by the types of activities in which the students engage (GARRETTRUCKS, 2016). They could, for example, spend time together preparing meals together or engaging in sports. Support of local authorities is ensured by giving the participants permission to enter student communities of a given university.

\section{The study}

\subsection{Rationale, setting and aim}

The rationale of this study stems from the authors' interest in intercultural foreign language (FL) education. Although India, where the author is based, is a heterogeneous country and students are exposed to a multiplicity of cultures, the same fails to translate into university classrooms, where intercultural input is limited. 


\section{movim nto \\ revista de educação do \\ programa de pós-graduação \\ faculdade de educação \\ ano 7 - número 15 - 2020}

Classroom instruction offers them few channels to experience and understand intercultural communication. Likewise, the level of internationalisation of Indian universities is extremely low. While Indian students travel abroad for holidays, use the Internet and other forms of media, and interact with individual. It is, however, difficult to determine the quality of such contact and the extent to which students experience the difference between their own perception of reality and that of people who are culturally different and whether students reflect on their contact with representatives of diverse cultures.

This makes it imperative to investigate and evaluate alternatives for moving students to higher levels of intercultural sensitivity. The research was intended to investigate students' perceptions of the development of intercultural competence i.e. knowledge, skills and attitudes developed through exploring their experiences during stays abroad. The author wished to assess whether and to what extent the students "transformed" in an international environment and became more openminded and inter-culturally competent, and in other words, whether the sojourn abroad translated into their intercultural development. In the study, intercultural contact was perceived as personal, direct contact with native and non-native speakers of English as a lingua franca ("any use of English among speakers of different first languages, for whom English is the communicative medium of choice, and often the only option"). Contacts with cultural products or representatives, primarily the various types of media such as the television, internet, books, movies, and magazines, though having high capacity as possible mediators of intercultural information and availability within India; were outside the scope of the research.

The study, exploratory in nature, was guided by the following three specific research questions:

1. To what extent did students engage in meaningful intercultural interactions?

2. To what extent did they reflect on their cross-cultural experiences and how did they interpret their interactions?

3. How did intercultural contacts, in students' view, change them and their attitudes or preconceived notions about their culturally different peers? 


\section{movim nto \\ revista de educação do \\ programa de pós-graduação \\ faculdade de educação \\ ano 7 - número 15 - 2020}

\subsection{Method}

Given the complex nature of both the phenomenon being studied and the research questions, a qualitative approach was adopted, which allowed for a more direct method of gauging the researched problem.

\subsection{Participants}

The participants were Indian students who came back to India after studying for one or two semesters abroad as part of "joint-degree program" and necessarily studied at least one paper about the host country's language and culture. An interview sample was chosen from four elite private universities, two large and two middle-sized private universities, located in Delhi, Andhra Pradesh, Haryana and Karnataka. The student body at all the four universities were very homogeneous: students from high income families, and where the universities had extremely low number of international students $(2.05 \%, 3.69 \%, 2.73 \%$, and $4.88 \%$ respectively). All the students listed in university's databases were e-mailed and invited to participate in the study. The response rate was exceedingly small and only 13 of the students agreed to be interviewed.

One student was excluded from the sample since he came from a multilingual family and the study focused on students raised and socialized in monocultural and mono- or bi-lingual settings. The logic of purposive sampling to increase validity of the study was followed (CORBIN; SILVERMAN, 2013). Ethics approval based upon informed consent procedures was followed. The sample of 12 interview participants varied across the attributes of gender, class year (age) and level of studies. The demographics of the accessed participants included a close to equal gender split with 7 females and 5 males.

There was also a diversified representation of age among the participants: from 20 to 25 . Almost half of the sample was graduate students (5), while the remaining participants were undergraduates (7). Their majors ranged from law, engineering, to management and liberal arts. All the participants spoke English at an advanced level of proficiency, high enough to be able to participate in courses, lectures and seminars in English while they studied abroad. The majority knew 


\section{movim nto \\ revista de educação do \\ programa de pós-graduação \\ faculdade de educação \\ ano 7 - número 15 - 2020}

another foreign language or even two, learnt from school, private lessons and selfstudy. During their study-abroad programme, they studied in as many as 10 countries: US, Canada, Great Britain, Australia, China, Italy, Singapore (2), Portugal, Japan and South Africa (2), in the span of either one (9 students) or two semesters (3 students).

All the participants were unfamiliar with the interviewer. To make sure that the participants had no prior experience of extensive intercultural contacts, they were asked whether they had ever lived abroad for a longer period or had a relationship in India with a foreign partner. No such experience was reported (one student worked in Singapore for four consecutive summers but was surrounded by fellow Indian workers). In addition, no interviewee participated in intercultural training prior to the sojourn.

\subsection{Data collection and procedures}

The author carried out semi-structured interviews with the participants of the study. The researchers not only asked a set of prepared questions but also followed the participants' lead. To avoid response bias (students offering acceptable responses) and over-directiveness, the students were prompted to add their comments freely during the interviews and make digressions. The interview questions were piloted with one student from the target population to check for clarity, which resulted in a few changes in their wording to resolve the ambiguities. The interviews were conducted in India, in the summer of 2019, by the author himself, recorded and transcribed verbatim. In order to keep the identity of the participants anonymous, their names were replaced by symbols (from S1 through S12). Recording allowed an in-depth analysis of the way the students' stories were told and the tone of the comments. The scripts were coded for units of meaning. Such procedures were employed to follow rigor demanded by qualitative research and to achieve more valid findings. The interviews took place individually - three took place in CCD (cafeteria), while the remaining ones were done via Skype. The interviews took from 35 to 60 minutes, amounting to the total of 549 minutes ( $M=$ $45.75 ; \mathrm{SD}=8.44 ; \mathrm{CV}=18.45 \%$ ). 


\section{movim nto \\ revista de educaçāo do \\ programa de pós-graduação \\ faculdade de educação \\ ano 7 - número 15 - 2020}

The interviewing protocol revolved around 15 closed and semi-structured questions related to four topics, which were supposed to guide both the interviewer and the students. Firstly, the biographical data were collected, and the participants were asked about the country where they had studied, the reasons why they had decided to study abroad, and whether their objectives had been achieved. Secondly, the students were asked about their preparation before going abroad, namely whether, or not, they had tried to learn about the country, its inhabitants and culture where they were supposed to spend one or two semesters.

The interviewer was also interested in whether, or not, they had taken part in intercultural training. The interviewees were questioned about their prior intercultural experience and whether they had travelled individually before or had lived with or kept in touch with an individual from another country on a regular basis before the sojourn. This question was designed to eliminate from the sample, individuals, with close and regular cross-cultural contacts prior to their sojourn.

One question was related to the length of time the interviewees spent with people from diverse cultures (both foreigners and locals), which was relevant so as to determine the potential effect of the sojourn on the students. Seven questions about students' experiences with contact with both locals and foreigners were meant to explore their intercultural awareness and notice to what extent it had changed (i.e., grew). The questions from this group also checked students' intercultural learning and asked whether the students had experienced a culture shock - the interviewees were prompted to discuss critical incidents they had experienced during their sojourn. The critical incident approach was utilized in this part of the study since it is considered a valuable research tool, especially with respect to understanding intercultural interactions and stimulating reflective thinking, which leads to reflective judgment, an important aspect of intercultural competence ( ALAM, A., 2020b; WINKLER; TANG, 2009; YUEN; GROSSMAN, 2009; ZHOU; PAGE-GOULD; ARON; MOYER; HEWSTONE, 2019).

The interviewer ended each interview session by asking the students to selfreport in detail on the changes they had observed in themselves following their stay abroad. The researcher also asked the participants what they had learned about 


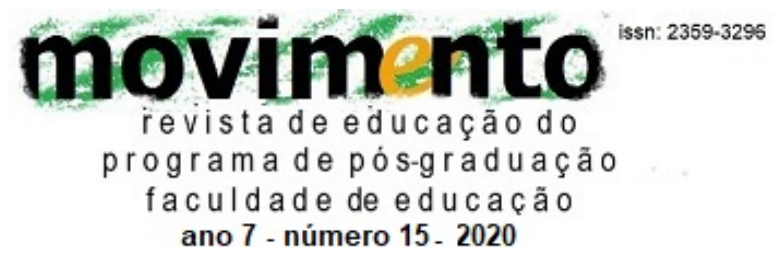

themselves and whether and to what extent they perceived themselves in a new way after the sojourn abroad. The final question concerned the changes which the respondents noticed in themselves and what, in their views, contributed to their development.

\subsection{Data analysis}

Following the principles of comparative analysis (ALAM, A., 2020a; WHALEN, 2015; WILKINSON, 2007; WINKELMAN, 2005), the researcher used coding to identify the key categories. The data was analysed in several steps. These categories were then grouped into the following themes:

1) Aspirations and expectations of the intercultural experience

2) Cultural knowledge and attitudes related to the lifestyles of various communities represented by the host country community and fellow Indian students. This includes housing, health, eating, drinking, clothing, festivities, and safety.

3) Similarities and differences between India and the host country

4) Realizing and overcoming stereotypes associated with different nationalities

5) Critical incidents and experiences with regards to culture shock

6) Intercultural contact and personal coping strategies

\section{Results and discussion}

The results of the data collected during the interview are presented as per the three research questions and the themes identified at the stage of data analysis.

\subsection{Expectations}

A significant number of participants declared that the desire for exposure to a novel culture and to gain foreign language proficiency had been the primary reasons for them to study abroad (S2, S3, S5, S7, S9, and S11 interviewees respectively). The afore mentioned aim appears to be pertinent because the students were unfamiliar with the culture and wished to communicate adequately and effectively. This outcome confirms the study by Alam, A; Kumari; Alam, S. (2018), Waßmuth; Edinger-Schons (2018), Werth; Lord (1992), West (2009). 


\section{movim nto \\ revista de educação do \\ programa de pós-graduação \\ faculdade de educação \\ ano 7 - número 15 - 2020}

Many students explicitly stated that there was a positive relationship between English language development and their sojourns. They maintained that studying abroad reduced their anxiety with regards to communication in English language. "At first, I was reluctant to talk to local and other foreign students because of a language barrier but step-by-step I managed to overcome it" (S5).

The participants did not perceive English as a threat to their national identity, the results thus supporting the outcome of the study by Alam, A.; Kumari (2017), Varela (2017), Vezzali; Stathi (2016), Walton (2009), Wandel (2003). Since community is rooted in communication, this finding demonstrates that students were well-equipped to engage in meaningful interactions when they were abroad.

The claim concerning the educational advantages of student mobility as an opportunity to learn the language and familiarise oneself with another culture was supported by a range a studies, one of them was by Alam, S. e Raj (2017), S TingToomey (1999), Turner (2010), Van Binsbergen (2003), Van Hook (2000).

Similarly, confidence in English language proficiency seems to be related to the ability "to develop a sense of identity and intercultural citizenship through English" (ALAM, S., RAJ, 2018; SILVERMAN, 2013; STEPHAN, 1987; SZABÓ, PAPP, LUU, 2020; THOMLISON, 1991). Three of the students emphasized that they always wanted to live in "the Indian bubble", i.e., surrounded by other Indian students from a range of different states. Six respondents wanted to cultivate new friendships. These answers indicate that the participants showed interest in the exploration of diverse cultures. This further shows evidence of their developed motivational domain of culture intelligence (CQ), a fundamental predisposition for becoming intercultural. The interviewees' decisions to study abroad partially stemmed from the cherished family traditions, for instance, all but one of the students acknowledged traveling abroad every summer before the sojourn. This corroborates previous studies which show that students who are willing to study abroad constitute a particular subset of people and, more specifically, those who possess huge cultural and economic capital (GONÇALVES, CARPENTER, 2013; GREEN,K., 2007; GUMPERZ, 2014; HANSON, 2017). 


\section{movim nto \\ revista de educação do \\ programa de pós-graduação \\ faculdade de educação \\ ano 7 - número 15 - 2020}

\subsection{Intercultural experience}

The interviewees did not consider intercultural contact as merely being a student at a university attended by other international students. The collective narrative revealed that they did their utmost to ensure that their stays abroad would go beyond mere presence in the proximity of local students. The participants were aware that learning about new cultures demanded active and direct forms of personal engagement - getting involved in meaningful communications with individuals who were raised in culturally different backgrounds. They thus formed numerous acquaintances that yielded discussions on a range of issues including culture and cultural differences.

In the interview sessions, the students declared that their peers from different universities and from different states of India whom they encountered in the host country constituted their primary social group in the sojourn. The students viewed them as representatives of diverse cultures. They realised that the new friendships were inseparable from and dependent upon their culture. However, they were not treated as strangers and quickly integrated into the students' social circles. The respondents perceived interaction with them as intercultural and realized that such encounters could create a range of impediments that both sides would have to overcome. The interviewees demonstrated evident curiosity and interest in students from other national groups and were open-minded in terms of different cultural identities. They sought and seized opportunities with their study-abroad counterparts and local students. In fact, in the interviews they reported socializing in an international, multi-national group, and two students declared that they had socialized primarily with host country students - they had local romantic partners.

Researchers investigating the contact hypothesis in the context of student mobility focused on the sojourners' integrative experience within the host society. This, however, was not reported by the students interviewed in the current study since their immersion in the host culture was solely based on contact with local students.

The opportunity to directly observe and engage with the local people and their culture may, therefore, have been limited. Experience of and participation in the host culture may have served to pique the curiosity of the participants in the 


\section{movim nto \\ revista de educaçāo do \\ programa de pós-graduação \\ faculdade de educação \\ ano 7 - número 15 - 2020}

same, prompting them to explore it profoundly and consequently helping them achieve a greater level of awareness of the diversity among the people and within the host country. The data collected confirms the findings by Ashraf (2020), Schauer (2009), Schiappa, Gregg e Hewes (2005), Schwieter, Ferreira e Miller (2018), Shook e Fazio (2008).

The participants tried to limit the time spent with Indian students to maximise the benefits of exposure to foreign cultures and otherness. Only a single student had to share a dormitory room with an Indian student, whereas six had a single room, five shared a room with an individual from a foreign country and none shared a room with a student from the host country. All the interviewees often partook in informal conversations in English. The acquainted themselves with local students who attended their classes and spent significant amounts of time with them in several distinct ways such as by visiting tourist attractions and associating with them at social events and gatherings. They were therefore, to an extent, immersed in an environment characterised by cultural diversity. Their lives were inherently interwoven with intercultural interactions. This allowed for the interpretation of their circumstances, along with an analysis of the response of nationally and culturally diverse students along with an assessment of critical situations and their consequences. The following excerpts from the interviews illustrate this:

“...most of the time I hung out and socialized with international students..." (S3).

“...I did not spend time with Indian students at all since I wanted to practice my English..." (S5).

“...I went on several excursions organized for students by the program coordinators and visited a few places..." (S10)

“...I spent $99 \%$ of the time with foreign peers, mostly with local students..." (S12).

\subsection{Cultural knowledge, diverse lifestyles, similarities and differences with India}

As previously mentioned, the students primarily socialised with their international counterparts and, to a lesser degree, with local students from the host country. The lack of daily contact with host communities permitted them only to 


\section{movim nto \\ revista de educação do \\ programa de pós-graduação \\ faculdade de educação \\ ano 7 - número 15 - 2020}

scratch the surface of their host cultures. It must be acknowledged, however, that the sojourn provided the interviewees with substantial scope to make critical discoveries about themselves and others. The students voiced rather conciliatory and level-headed judgements about life in a particular foreign culture. Moreover, positive attitudes towards cultures prevailed in their accounts.

Various instances were illustrated throughout the interview. According to the interviewees, life was much more fast-paced in India as compared to that in the US, Canada, Great Britain, Australia, Italy, Portugal and South Africa. Maintaining a synergy between professional and personal lives was of utmost importance for the locals. They also noticed that the speed of life may differ within a particular country: "Toronto is faster than Halifax" (S2). Several countries had an entirely different schedule in terms of mealtimes. Dinner is the main meal, served in the evenings (Portugal, Italy). In many countries there is a lunch break during the day; however, quite surprisingly, "in north-eastern China, which is more developed, there are no siestas" (S3). Healthy food is extremely popular in Great Britain: "There are a lot of vegans and vegetarians" (S9). In contrast, "semi-finished food products are widely purchased and consumed in US. Because of geographical reasons, national cuisine is not much developed there, with onions and fish being extremely popular among the Japanese" (S11). Coffee drinking has been ritualized in Italy: "Italians drink different coffee types at various times of the day, in a seated or standing position, depending on the circumstances. Furthermore, wine is widely consumed at dinner, even by children, for whom it is served diluted" (S3). In Australia, "beer is loved; diverse ranges have to be drunk in a specially designed glass" (S12). In South Africa, "wine is mixed with carbonated soft drinks" (S5).

As per the students' narratives, the dress code appears to have standardised across the countries. The same brands are available in all countries: "I met in China a girl wearing the same jacket as the one I purchased here in India" (S5). However, they recognised certain distinguishing trends and features in this respect. As an exemplification, the Japanese and the Chinese pay comparatively less attention than the Indians to what they wear: "Women in tracksuits and without make-up shopping in a mall are characteristic of the Chinese landscape" (S9). One interview 


\section{movim nto \\ revista de educaçāo do \\ programa de pós-graduação \\ faculdade de educação \\ ano 7 - número 15 - 2020}

respondent was surprised that "women in Japan wear tracksuits at very formal occasions along with expensive jewellery" (S5). Other student said that "the Canadians get dressed only to be warm and not to stand out" (S11), "the Portuguese wear thick jackets in relatively high temperatures" (S5) and "the Singaporeans wear extravagant and eccentric outfits; for example, males wear colourful socks" (S12).

The participants noted unique dressing traditions at some universities. Law students in Portugal, for example, wear special coats resembling capes. In fact, "they were the prototypes for J. K. Rowling's characters in Harry Potter" (S1). Students in the United States can be distinguished by kinds of trousers: "Each university has a different type" (S11).

It may come as a surprise that stereotypical views were so ubiquitous in the students' narratives. This might gave stemmed from the fact that their knowledge of the life of the locals was solely based on casual meetings in public places and allowed only for surface observations. Additionally, the majority studied in large cities with a substantial flow of tourists, which also shaped, blurred, and distorted the landscape.

The interviews demonstrated that the participants had largely gained insight into surface issues like clothing and food; their observations seem quite simplistic and, as in many other studies, including Kumar, Kumari \& Alam (2018), Powers (2018), Ray (1983), Ren (2015), Romanowski (2017), Salisbury, Na \& Pascarella (2013), show quite an "external" perspective on the part of the participants.

The findings of the current study demonstrated that most of the students show propensity to minimize cultural differences, which is characteristic of the minimization phase in (BENNETT, 2004). In this stage, individuals share the generalized belief that everyone is fundamentally the same, and differences are acknowledged but minimized and perceived as unimportant, compared to cultural similarities. However, some of the respondents were alert to differences and peculiarities concerning the host country in many more domains:

“...in China people leave shoes outside while entering houses..." (S9).

“...Japanese spend a lot of time in cafes. This refers also to old people..." (S10). 


\section{movimento \\ revista de educação do \\ programa de pós-graduação \\ faculdade de educação \\ ano 7 - número 15 - 2020}

“...people from Great Britain value highly their personal zones, which is manifested by keeping a larger physical distance with an interlocutor. They seem to be very calm, self-oriented and never say "Can I help you?" when they see something wrong is going on with you..." (S11).

"...in Canada people do not say thank you after meals. At first, I found it irritating, because for me it is an expression of gratitude to a person who dedicated her/his time to prepare a meal. Once I asked about this the local people, I learned that cooking, in their opinion, is perceived as enjoyment on the part of the person who did the cooking..." (S12).

In two accounts, the issue of safety was discussed. For example, Great Britain seemed to be exceptionally safe for one respondent:

"...I was surprised there was no need to padlock bicycles. On trains passengers left their valuable laptops unattended and went to a dining car. In both cases nothing disappeared..." (S11).

In a similar vein, one student noted a strong, in her opinion, social trend:

"...I was surprised that in a liberal US still a patriarchal model of family dominates, i.e., it is a woman who cooks meals, the model is even duplicated among young couples, a great number of young women want to be housewives. In addition, 'to be' over 'to have' approach to life prevails..." (S12).

\subsection{National stereotyping}

Although the interviewees reported that student mobility has increased their interest in other countries, their people and their cultures, yet broad national stereotyping is evident in their reports. For instance, their narratives revealed that the beliefs that people from Great Britain, China, and Japan are very family-oriented: "...the Japanese care about order around their home vicinity and foster the culture of transparency, manifested, among others, by houses with large, free-from-curtains windows. They leave their shoes outside before entering the house. Furthermore, they are crazy about DIY, probably due to bad weather. They are also nicer, much more sincere and more direct in contact than Indians. Generally, the Japanese are more interested in their own lives than in other people's affairs..." (S4). 


\section{movim nto \\ revista de educação do \\ programa de pós-graduação \\ faculdade de educação \\ ano 7 - número 15 - 2020}

"...the Indians are often late and very loud..." (S1) . . ....and so are the South Africans, especially women..." (S2).

"...the Chinese like to be on the go and work a lot..." (S10),

"...the Canadians love celebrating together and are very attached to their traditions. They even organize the birthday of the street's patron..." (S2).

"...the people from Great Britain are quite reserved and withdrawn. I had to initiate interactions..." (S12).

Their accounts also evidenced the different organisational methods of university education in different countries:

"...in China, the university infrastructure is well-developed, and tons of hand outs are distributed in classes/lectures..." (S6).

The data from the interview revealed that all but one student was involved in partner or group projects and collaborations with representatives from a range of countries. Four of them claimed that they believed that their international peers were representatives of their nationalities but noticed no difference in their methods of working. The remaining seven reported quite a large diversity with regards to working styles across cultures. Their reports, however, largely comprised culturespecific generalizations and stereotyping. When the students referred to certain complaints against their international counterparts, they seemed to give more relevance to the nationality of the student as opposed to individual behaviours such as (the lack of) commitment and responsibility that are considered universal values.

This indicated at the belief that there was a causal relationship between the country of the origin of an individual and their performance, rather than the quality of work being simply a matter of individual approach.

The sample was not homogenous in the accounts with regards to the how their international peers worked in class. Some interviewees used national labels in their reports, explicitly showing disregard for or bias toward the national group in question, which confirms the findings of previous studies, e.g., Kumari \& Alam (2017), Salisbury et al.(2013), Schauer (2009), Schiappa et al. (2005), Schwieter et al. (2018). 


\section{movimento \\ revista de educação do \\ programa de pós-graduação \\ faculdade de educação \\ ano 7 - número 15 - 2020}

Italian students, for instance, were presented as neglectful, absent-minded, and irresponsible. They were not willing to get involved in projects and were indifferent to deadlines. They largely communicated using social media:

“...they avoided face-to-face contact outside the class..." (S3).

Female students from US wanted to cheat:

"...we were supposed to create our own start-up, they wanted to resort to the one already set up by somebody else..." (S10).

Nevertheless, negative attitudes were generally well-balanced with positive ones. One student reported that:

“... a female student from Portugal stood out because of her high English proficiency and she approached every single task very seriously..." (S6).

Another noted that:

"... a male student from Australia was always late but very conscientious..." (S9).

South Africans were perceived as remarkably similar to Indian people.

“...I liked working with Canadians most. We distributed subtasks, everybody did his/her share of the work, and they met deadlines..." (S11).

Some interviewees went beyond national stereotyping in their descriptions, which is well illustrated by the following comment:

“...the experience of group-work with international students convinced me not to resort to national labels when assessing people - the way a person works depends on his/her individual characteristics and approach to work, and not on the country he/she originates from..." (S10).

The collected narratives, however, marked a discrepancy between selfreported data and cultural attitudes as analysed above. The majority of the respondents claimed that they tried to be culturally conscious in interactions with international peers - they tried to be unprejudiced, rejected tokenizing and showed goodwill and sincerity toward their culturally diverse interlocutors.

They tried to listen to others and their experiences; if confronted with something unfamiliar or incomprehensible, they resorted to observation, analysis and exploration. If they could not understand something, they researched by themselves or asked their interactants for explanation. A few reports revealed that 


\section{movim nto \\ revista de educação do \\ programa de pós-graduação \\ faculdade de educação \\ ano 7 - número 15 - 2020}

the students viewed culture from a specific, country-related and nation-bound perspective, especially in reference to their Muslim peers. The story of one male respondent insinuated that the sojourn had strengthened his stereotypical thinking concerning Muslims. He considered his Muslim South African peer to be very patriarchal and demonstrated superiority towards women, and believed that men shall enjoy a superior position compared to women:

“...I was shocked when I noticed he never shook hands with women while doing it with men, nor targeted them directly in a conversation..." (S11).

Other respondents admitted that they were pre-emptive and "tried not to talk about religion so as not to provoke conflict" (S1).

Such nation-bound understanding of culture is perceived as a serious impediment to cross-cultural contacts. Many stories narrated by the students showcased contrasting behaviours in a single representative of a particular nationality. The first-hand experience of the interviewees confirmed for them that people from the same culture can differ tremendously.

One student noticed inconsistencies in the ways in which the Muslim students approached their religion:

“...my South African fellow student, on the one hand, practiced Ramadan, but, on the other, did not abstain from toxic substances or alcohol, which his religion prohibits..." (S4).

Two interviewees were struck by the religious commitment of their Muslim peers. The Muslim fellow students prayed five times a day; one had religious symbols on her desktop wallpaper and was eager to discuss her religion, and the other had a special application on her phone to remind her of prayer times. One female Muslim student wore a hijab even in the shower:

“...it never proved problematic for her; she perceived this as routine..." (S9).

It thus seems safe to conclude that, while national stereotyping was commonplace in the interviews, contact with international students increased the study participants' awareness of diversity, which would likely be conducive to an increase in the students' sensitivity with regards to cultural differences in the future. 


\section{movimento \\ revista de educaçāo do \\ programa de pós-graduação \\ faculdade de educação \\ ano 7 - número 15 - 2020}

\subsection{Cultural shock and critical incidents}

The bulk of the participants did not experience cultural shock, assumedly because all of them belonged to wealthy, affluent families and consequently made extensive use of movie streaming applications such as Netflix and Amazon Prime and thus had prior knowledge about foreign cultures. Many interviewed students highlighted that cultures are somewhat homogeneous:

"...in contemporary globalized world there is not much diversity between countries..." (S9).

Some participants were particularly surprised at the similarities:

"...I thought countries differ much more..." (S11).

Only one female interviewee who had studied in United States mentioned being shocked at a job interview - she expressed discomfort about being kissed on both cheeks by the interviewer, a complete stranger to her. According to Alam, A., (2020), Pettigrew \& Tropp (2005), Plews \& Misfeldt ( 2018), Pochebut \& Logashenko (2014) and Powers (2018), negative experiences with individuals from other cultures may turn out to be valuable and promote intercultural development.

The narratives of the other students, however, did not indicate such conspicuous cultural differences - they noticed and reported much dissimilarity between life in the host country and in India, they were never confronted with behaviours by individuals of other cultures that were inappropriate or a violation of personal space. This corroborates previous studies as Peng, Wu (2016), PérezVidal (2014), Petrovskaya, Shaposhnikov (2020) and Pettigrew (1986).

All but one interviewee reported witnessing no critical incidents during their sojourns. The narrative of the student who experienced what he considered a perplexing situation was attributed to cultural distinctions:

"...I wanted to shake hands with a Muslim girl from Great Britain I met, but she refused (stepped back), which I found rather surprising. But I apologized quickly. I didn't know female Muslims can't shake hands with men..." (S8).

Lack of knowledge in such aspects may have resulted from the fact that, as indicated above, the participants spent most of their time abroad on campus or 


\section{movimanto \\ revista de educação do \\ programa de pós-graduação \\ faculdade de educação \\ ano 7 - número 15 - 2020}

accompanied by local students at social events. Outside of this, interaction with locals was minimal.

\subsection{Reflecting on intercultural experiences}

The interviewees appreciated the ample opportunities that the study abroad programmes provided them, especially in terms of interaction with culturally diverse students. They viewed them as "bonuses" or "added value" of student mobility. They were eager to interact with foreigners since this is not commonplace in India. Moreover, participants stated that direct, meaningful contact with individuals from other countries caused them to reflect and retrospect not only about the situations they found themselves in, but also their standpoint and behaviour towards other cultures.

Analysing various intercultural situations led to the respondents' understanding of the ways in which cultural contexts affects different aspects of their lives. This finding confirms the outcomes of other researches on studying abroad in this respect, showing it as a positive experience leading ultimately to growth in participants' ICC development e.g., Moore, Simon (2015), Nganga (2006), Nunez (2007), Paluck, Green, A., Green, P. (2019).

According to intercultural contact scholars, recognizing interlocutors as culturally diverse representatives of a specific cultural group is a precondition for an opportunity to rethink an individual's attitudes toward otherness and reduce their prejudices and biases (MELEADY, SEGER, VERMUE, 2020; MENG, ZHU, CAO, 2017; MICKUS, BOWEN, 2017; MILLER, BREWER, 2013).

As evidenced from the collected data, the interviewed students utilized their sojourns in this respect by practicing reflective thinking, the capacity leading to reflective judgment, which appears to be critical for intercultural development: “...I tried to reflect on my intercultural experience on a daily basis and tried to refer my observations to my future decisions, situations. At first same sex couples holding hands or kissing each other in public shocked me, but step by step I tried to understand why they did this..." (S1). 


\section{movim nto \\ revista de educação do \\ programa de pós-graduação \\ faculdade de educação \\ ano 7 - número 15 - 2020}

"...I tried not to assess people. Instead, I focused on careful observation, analysis and interpretation..." (S2).

"...I tried to understand their perspective and asked a lot of questions..." (S3).

"...study abroad was an impulse to self-analyse. I developed a social instinct..." (S4).

The data demonstrated that in face-to-face contact with peers from other cultures the students were very mindful and paid attention to cultural differences and social nuances, which yielded helpful insights and deeper understanding of cultural differences:

"... in Portugal, dinner is eaten a little later than in India..." (S1).

"...I witnessed how graduation is celebrated in Italy among friends. Flour and eggs are thrown at a graduating student, and finally he/she is forced into water fully dressed..." (S3).

Simultaneously, direct interactions with students from a range of diverse cultures raised the respondents' awareness of their own cultural identity. Most of the interviewees tried to be ambassadors of their country, which was manifested, among others, by preparing popular Indian dishes for international fellow students, explaining Indian customs to them, exhibiting the Indian flag in a room or debunking the unfavourable myths surrounding India and Indian people:

"...I am proud to be Indian, especially of Indian traditions, which, in my opinion, should be cherished. I was among the students who organized an event on India's Independence Day. I even wore a traditional folk costume..." (S2).

“...when we organized India's Independence Day, I plaited my hair in a typical Tamil way and prepared Idli and Sambar..." (S7).

"...although I admired "perfect order" and planning in Great Britain, I realized that Indian spontaneity suits me fine. I noticed that Indian grocery products are of a much higher quality, that is, not always packaged. I tried to talk a lot about India and encouraged my fellow international students to visit my homeland, simultaneously trying to reject the stereotype of India as a worse, third world underdeveloped country of snake charmers..." (S8). 


\section{movim nto \\ revista de educação do \\ programa de pós-graduação \\ faculdade de educação \\ ano 7 - número 15 - 2020}

The participants' engagingly honest comments showed that they did not approach foreign cultures ethnocentrically. Although they sustained some "home preferences," for example, regarding eating and drinking, did not compare foreign practices unfavourably with the more familiar ones in India. Their response to cultural difference was not negative. No patronising or disparaging remarks were made with regards to foreign culture, indicating that the students did not perceive their own culture as superior. They attempted to be objective, occasionally even reformulating certain ideas and providing unfavourable assessments of India and its inhabitants:

“... Indian people are still much closed, full of prejudices and fears of all kinds, reluctant to start or meet anything new..." (S6).

The respondents discussed other cultures with great respect and held a realistic view of their homeland:

"...I like the Australian culture of transparency, manifested by leaving the windows open, which allows passers-by a full view of your living quarter and shows that you have nothing to hide..." (S4).

They did not adopt a censorious stance about their host culture. This evidences the development of the students' worldviews and their progress on Bennett's DMIS ethnocentric/ethno-relative continuum (LAI, 2006).

Occasionally, however, a reinforcement of their identity as Indian nationals was observed, particularly when their international counterparts showcased ignorance and lack of the most trivial of knowledge about India:

“...it got on my nerves when they asked me whether there were shopping malls in India..." (S2).

"...I found it frustrating that the local students from Great Britain didn't know about their country's history, their colonial past and the role of Mahatma Gandhi in the Indian freedom struggle and ultimately their victory..." (S4).

The students attempted to understand, analyse and contextualize the daily practices of the representatives of diverse cultures, principally of their local and international counterparts. In accounts of cross-cultural contacts where elements of criticism appeared, the respondents adopted the perspective of "general culture" - 


\section{movimento \\ revista de educação do \\ programa de pós-graduação \\ faculdade de educação \\ ano 7 - número 15 - 2020}

they resorted to cultural norms that are universal and applicable in a wide range of contexts, an indicator of intercultural development.

One female respondent explicitly expressed her dislike toward the feminization of men and described it as a worldwide trend. Although she observed it in a specific national context, i.e., Italy, her desire for a change applied in a wider context:

“...in Portugal, men are overly concerned with their look. An Italian male friend of mine constantly took photos of himself in different settings to exhibit it on the Instagram, which I found bothersome and unmanly. There is a need to initiate a crusade for maintaining masculinity..." (S1).

\subsection{Developing personal coping strategies}

Narratives of few students demonstrated that contact with peers from other cultures prompted them to develop a range of strategies helpful in cross-cultural situations, which mirrors the results of other researches as Mapes (2020), Maran \& Stockhammer (2013), Martin \& Nakayama (2013); Matkin (2005).

One female participant said that "dialog is the key to understand another individual and solve any hurdles in cross-cultural encounters". Moreover, the participants of the study learnt that individuals from different cultural settings may have different expectations and anticipations, and that this may lead to misunderstanding and miscommunication. The students tried to limit initial assessments of their international peers:

“...I tried not to judge people, and instead attempted to be mindful and observed them attentively..." (S2).

If and when they evaluated them, they made efforts to "understand their perspective" (S3) or "to put themselves in their shoes and be empathetic toward them" (S12). One respondent commented: "I became more mindful - I listen to people more attentively" (S4).

The respondents mostly stated that if they encountered a puzzling or unfamiliar situation, they questioned their interlocutors in order to elicit an explanation. This was in accordance with recommendations by experts in the field 


\section{movimento \\ revista de educaçāo do \\ programa de pós-graduação \\ faculdade de educação \\ ano 7 - número 15 - 2020}

of intercultural communication, namely, (STELLA TING-TOOMEY, 2009) who, in her O-D-I-S model, encouraged individuals to observe, describe, interpret and suspend judgment when confronted with foreigners and, more recently, by Berardo \& Deardorff (2012) in their O-S-E-E model: observe, state, explore and evaluate.

Some respondents revealed that they compared their foreign counterparts' seemingly strange behaviours or opinions and attempted to find similarities with the ones typical of the Indian culture. The students had a proactive approach to crosscultural conflicts - they tried to foresee and anticipate them and either used an avoidance strategy or modified their behaviour to evade dispute.

\subsection{Changes in attitudes, views and behaviour}

This study confirms previous research like Lai (2006), Landis, Bennett, J., \& Bennett, M., (2003), Lantz-Deaton (2017), Llanes, Cots Caimons, Mas-Alcolea \& Aguilar Pérez (2016), Lou (2012) e Mansouri \& Vergani (2018), in that all the students reported a change in attitudes, views and behaviour. This further supports the developmental and context-based nature of ICC (KÖNIG, 2019; KORHONEN, 2010a, 2010b; KRIEBERNEGG, MAIERHOFER, PENZ, 2014; KUDO, VOLET, WHITSED, 2017).

However, the extent of the students' transformation is not even, and some reported a more profound change than others. An essentialist approach to culture and stereotyping were present in some narratives. The extent to which the interviewee developed the sense of an inclusive, intercultural identity that goes beyond their nationality (KLOPF, 1998; KOBAYASHI, 2009; KOMISAROF, HUA, 2015) is not apparent.

Five students explicitly stated that although they were initially biased against foreigners, the sojourn changed their views:

"...Chinese are conscientious and much more hard-working than what I initially thought. They are not as self-confident as I imagined - I have never met a shy Chinese before..." (S6).

"...the South Africans ride their bikes more and use less toxic substances than I thought..." (S4). 


\section{movimento \\ revista de educação do \\ programa de pós-graduação \\ faculdade de educação \\ ano 7 - número 15 - 2020}

A few respondents admitted that the stay abroad helped them reject certain stereotypes:

"...contrary to what I thought before, the Americans do not come late..." (S6).

“...the Italians are not cold and do not keep people at a distance; contrary to this, their mind-set resembles that of an Indian..." (S11).

Two female interviewees admitted that they were prejudiced against Muslims, whom they associated with terrorism and restraint through headscarves. One of them mentioned that she was surprised that her closest relationship whilst abroad was with South African students:

"...through close contact, they turned out to be quite alike me: their views on many things such as women's emancipation seem to be similar to mine. They are tolerant toward homosexuality. Now I perceive their diverse clothing patterns as something positive..." (S5).

The other student realises that the picture of Islam, as painted in the Indian media, is biased:

“...I didn't know that killing is forbidden by Islam..." (S1).

The afore mentioned narratives proved that critical reflection resulted in the respondents' identifying assumptions that underpinned their stereotypical views, evaluating their validity and reconstituting their understandings.

The following narratives evidence more examples of the reorientations reported explicitly by the respondents:

"...I try to control assessing my interlocutors. I do it much less frequently now..." (S1).

“...I have learned to approach people unprejudiced and without categorizing or labelling them. I have realized it is necessary to listen to them first and explore the settings before coming to conclusions..." (S4).

“...I considered my truth to be the most important. Now I can understand another's perspective. Every individual has something valuable to contribute. I have started considering otherness as "added value" to an individual..." (S6).

“...I approach another individual with a fewer assumption about their identity in general..." (S7). 


\section{movim nto \\ revista de educaçāo do \\ programa de pós-graduação \\ faculdade de educação \\ ano 7 - número 15 - 2020}

"...staying among people from diverse cultures was something of an ordeal; in retrospect, however, my comfort zone has expanded tremendously..." (S8).

"...contact with foreigners helps an individual distance themselves from their own culture. I have broadened my horizons and became more inclusive; I have learned how to grapple with problems in communication with people from diverse cultures..." (S10).

"...I am more empathetic. I learned to listen to my interlocutors. I am more sensitive and open toward otherness and find it much easier to cope with representatives of the multicultural world. Whenever I find something strange or incomprehensible, I keep asking questions. I became more liberal..." (S11).

"...I used to judge people in a very shallow and superficial manner, often by forming snap judgments. Having spent one semester abroad, I have conclude that my assessment can be entirely invalid and inaccurate, generalizations are often of no value, and that each individual must be evaluated separately, depending on a specific context..." (S3).

"...some things may appear terrible at first sight, but it does not necessarily indicate bad intentions on the part of the interlocutor/s. I make efforts to pay attention to nuances of others' actions and words..." (S12).

According to the students, their sojourn was instrumental to their personal development, especially with regards to their increased maturity and confidence. They declared that their tolerance of other cultures and nationalities had heightened, and they made efforts to consciously avoid evaluative adjectives:

"...to initiate a conversation with or ask questions to individuals from different cultures is no longer a problem..." (S1).

"...never before did I witness a same-sex couple kiss each other in public. I became accustomed to this as time passed..." (S2).

"...I find it much easier to establish a connection with a Muslim now..." (S4).

"... it is much easier for me to find myself among people from other cultures..." (S10).

\section{Conclusions and implications}




\section{movim nto \\ revista de educação do \\ programa de pós-graduação \\ faculdade de educação \\ ano 7 - número 15 - 2020}

The study, based on interviews, illustrated that students attempted to be mindful in a diverse intercultural context and open-minded towards their international peers, and eagerly engaged in meaningful contact with them, regardless of the lack of formal preparation. The findings of this study align with other research on the effects of studying abroad, and are indicative of a largely positive experience for its participants; studying abroad develops sensitivity to cultural differences, and brings forth intercultural awareness and competence (HEWSTONE, BROWN, 1986; HUBER-KRIEGLER, LÁZÁR, STRANGE, 2003; IHLANFELDT, SCAFIDI, 2002; JACKSON, 2012; 2017; JACKSON, OGURO, 2017; KAUFFMANN, 1992; KERN, DEVELOTTE, 2018; KIEMELE, 2009; KILIAŃSKAPRZYBYŁO, 2017).

The sojourn expanded the students' surface knowledge about the host country and its citizens. The students took advantage of the ample opportunities for intercultural interactions. They principally communicated with other international students and, when confronted with incomprehensible situations, made commendable efforts to ask their interlocutors for explanations. However, they had little access to local communities and therefore could not fully immerse themselves in the host culture and its language. Their opportunities to fully understand it were limited. Consequently, they learned only to a limited extent that intercultural communication requires a lot of care and effort and practiced an application of considerate and reflective strategies moderately.

Nevertheless, with focus redirected to international peers, the interview sample tried not to generalise cultures and adopted a reflective stance cultural difference. This resulted in their preconceived notions of cultural groups being challenged, processed and, in some cases, reviewed. The students' narratives revealed that, while national stereotyping was prevalent, the exchange with their international peers changed their ingrained beliefs and views to a certain extent, promoting open-mindedness and inclusiveness.

The study implies that the sojourn was an opportunity for meaningful interaction with both domestic and international students and has considerable potential to enhance participants' global-mindedness and imbibe skills of 


\section{movim nto \\ revista de educaçāo do \\ programa de pós-graduação \\ faculdade de educação \\ ano 7 - número 15 - 2020}

acceptance and adaptation in general. Although the success of a mobility experience depends on several factors, some of which may be difficult to gauge or predict, the finding of this research implicates the pertinence of internationalizing study programs to foster students' intercultural growth.

On a practical front, therefore, study abroad programs of at least one semester must be a mandatory element of university curricula. Consequently, students would be exposed to foreign culture(s) and presented with opportunities to retrospect on the experience and act accordingly in future cross-cultural encounters, contributing, in the long run, to growth in their ICC.

The results demonstrate that student mobility in itself does not ensure intercultural development and the potential value of intercultural training - it is vitally relevant to ensure that students are aware of what they might encounter ahead of time, and what measures might help enhance their study-abroad experience. This would encourage students immerse themselves in the host country and its culture more eagerly and profoundly and would contribute to sharpening their mindfulness and retrospection during the sojourn. Likewise, appropriate support, evaluation, and opportunities for reflection upon the return are crucial to successful student mobility. This must be combined with teaching English as a global lingua franca at all levels of education.

Certain limitations of the study should be addressed. Firstly, the research was carried out after the students had returned home and consequently, not much was known about their ICC before their departure. A longitudinal study wherein the data be collected periodically, and participants would be interviewed before, during and after their stays abroad would be a valuable source of information since it would then provide greater opportunities for the analysis of the students' intercultural development.

Exploring the long-term results of students' mobility would require qualitative examination of the students' intercultural contact, which would manifest as maintenance of social networks established abroad, changes in lifestyle choices and their degree of civic engagement in the future. Critical reflection at all stages of the sojourn may have deepened the understanding of the experiences. With cultural 


\section{movim nto \\ revista de educação do \\ programa de pós-graduação \\ faculdade de educação \\ ano 7 - número 15 - 2020}

diversity, and its impact on intercultural learning, allowed for validating possibly overly optimistic conclusions drawn in this study.

Secondly, the applied methodology of semi-structured interviews was largely limited and, to an extent, shaped the participants' narratives. A proposed solution is a focus group with few interviewees to discuss certain themes further. Minimum involvement by the researcher and the lack of prompts would ensure that the participants expressed their unbiased opinions and would yield helpful insights into the researched issues.

Thirdly, the research was done on a small sample. Only those who volunteered to take part and were eager to report positively were part of the study; the conclusions, therefore, are preliminary and tentative, and cannot be extrapolated beyond the study group. To verify the results presented in this article and draw more reliable and valid conclusions, the study should be replicated on a larger, drawn sample of students at the tertiary level.

Fourthly, helpful insights could be gained by complementing the present retrospective and qualitative study with the data received from other sources, other than interview accounts such as those from students' diaries, journals, logs and eportfolios. This would validate the obtained data and thereby increase the credibility of its findings and their interpretation.

Additionally, the research documented only the perspectives of the participants. The effectiveness of the sojourn was measured retrospectively, from the students' point of view, based on their reports. Future studies should attempt to garner additional data sources and utilize a multi-perspective approach that could solicit evidence from both students and people with whom they interacted.

The evidence would further be strengthened by field observations of student performance in intercultural contexts, and interviews from instructors, host family members or community members. The use of a control group could bring considerable inputs concerning the extent to which the development of the students' ICC could be attributed to student mobility itself and not to other external factors that may have caused the changes. 


\section{movimento \\ revista de educação do \\ programa de pós-graduação \\ faculdade de educação ano 7 - número 15 - 2020}

Finally, additional studies with a broader multinational perspective that focus on Asian, African, and European students' sojourning abroad are necessary. Only the triangulation of methods and sources will allow us to further pursue and investigate the matter thoroughly, and eventually give an enhanced insight into the investigated topic and thus give reliable answers to the research questions. Shortterm study-abroad programs have an enormous capacity to increase participants' ICC, but their quality is contingent on a range of factors that are not yet fully understood. Greater effort is thus required to explore the international educational experience to foster students' intercultural development and to analyse the correlation between both.

\section{References}

ALADIA, Salomi. Influence of Study Abroad on Students' Cultural Attitudes, 2017.

ALAM, A Ashraf. Pedagogy of Calculus in India: An Empirical Investigation. Periódico Tchê Química, v. 17, n. 34, p. 164-180, 2020a.

ALAM, Ashraf. Possibilities and Challenges of Compounding Artificial Intelligence in India's Educational Landscape. International Journal of Advanced Science and Technology, v. 29, n. 5, p. 5077-5094, 2020b.

ALAM, Ashraf. Test of Knowledge of Elementary Vectors Concepts (TKEVC) among First-Semester Bachelor of Engineering and Technology Students. Periódico Tchê Química, v. 17, n. 35, p. 477-494, 2020.

ALAM, Ashraf, KUMARI, Meena; ALAM, Shamsher. Seventh Pay Revision Vis-àVis Higher Education in India. Indian Journal of Social Research, v. 59, n. 5, p. 719-733, 2018.

ALAM, S.; KUMARI, M. Tribal Heritage Conservation in Jharkhand from an Anthropological Viewpoint. Indian Journal of Social Research, v. 58, p. 913-924, 2017.

ALAM, S.; RAJ, A. The Academic Journey of Witchcraft Studies in India. Man in India, n. 97, p. 123-138, 2017. 


\section{movim nto \\ revista de educação do \\ programa de pós-graduação \\ faculdade de educação \\ ano 7 - número 15 - 2020}

ALAM, S.; RAJ, A. Witchcraft and Witch Hunting in India: An Assessment. Emerging Challenges of Violence Against Women, Odisha State Women Commission, Bhubaneswar, India, p. 21-25, 2018.

ALLPORT, G. W.; CLARK, K.; PETTIGREW, T. The nature of prejudice. In: Ang, S.; Van Dyne, L. Handbook of cultural intelligence: Theory, measurement, and applications: Routledge, 2015.

ARASARATNAM-SMITH, L. A. Intercultural competence. Intercultural competence in higher education: International approaches, assessment and application, 2017.

Armfield, P. A. An examination of the relationship between students' interaction with host nationals while on study abroad and their development of intercultural sensitivity, 2004.

Ashraf, A. Challenges and Possibilities in Teaching and Learning of Calculus: A Case Study of India. Journal for the Education of Gifted Young Scientists, 8(1), 407433, 2020.

Aveni, V. A. P. Study abroad and second language use: Constructing the self: Cambridge University Press, 2005.

Barkin, G. Either Here or There: Short-Term Study Abroad and the Discourse of Going. Anthropology \& Education Quarterly, 49(3), 296-317, 2018.

Bennett, M. J. A developmental approach to training for intercultural sensitivity. International journal of intercultural relations, 10(2), 179-196, 1986.

Bennett, M. J. Becoming interculturally competent. Toward multiculturalism: A reader in multicultural education, 2, 62-77, 2004.

Bennett, M. J. Developmental model of intercultural sensitivity. The international encyclopedia of intercultural communication, 1-10, 2017.

Benson, A. D; Joseph, R.; Moore, J. L. Culture, learning, and technology: Research and practice: Taylor \& Francis, 2017.

Berardo, K; Deardorff, D. K.. Building cultural competence: Innovative activities and models: Stylus Publishing, LLC, 2012.

Bianco, J. Intercultural encounters and deep cultural beliefs. China and English: Globalization and Dilemmas of Identity, 23-56, 2009. 


\section{movim nto \\ revista de educação do \\ programa de pós-graduação \\ faculdade de educação \\ ano 7 - número 15 - 2020}

Blasco, M.; Gustafsson, J. Intercultural alternatives: critical perspectives on intercultural encounters in theory and practice: Copenhagen Business School Press DK, 2004.

Bremer, K; Roberts, C; Vasseur, M.-T; Simnot, M; Broeder, P. Achieving understanding: Discourse in intercultural encounters: Routledge, 2014.

Brewer, E; Cunningham, K. Integrating study abroad into the curriculum: Stylus Pub, 2010.

Burrow, J. D. A Meta-analysis of the Relationship between Study Abroad and Intercultural Competence, 2019.

Caspi, A. Contact hypothesis and inter-age attitudes: A field study of cross-age contact. Social psychology quarterly, p. 74-80, 1984.

Chieffo, L. Here to stay: Increasing acceptance of short-term study abroad programs The handbook of practice and research in study abroad (pp. 387-402): Routledge, 2010.

Corbin, J. Anselm. Strauss. Basics of Qualitative Research: Techniques and Procedures for Developing Grounded Theory, 2007.

Cots, J. M; Aguilar, M; Mas-Alcolea, S; Llanes, À. Studying the impact of academic mobility on intercultural competence: a mixed-methods perspective. The Language Learning Journal, v. 44, n. 3, 304-322, 2016.

Crisp, R. J; Turner, R. N. The imagined contact hypothesis Advances in experimental social psychology (Vol. 46, pp. 125-182): Elsevier, 2012.

Cubillos, J; Ilvento, T. Intercultural contact in short-term study abroad programs. Hispania, 101(2), 249-266, 2018.

Cushner, $\mathrm{K}$. The role of study abroad in preparing globally responsible teachers The handbook of practice and research in study abroad (pp. 173-191): Routledge, 2010.

Deardorff, D. K. Theories of cultural and educational exchange, intercultural competence, conflict resolution, and peace education Cultural and educational exchanges between rival societies, p. 23-38, springer, 2018.

Dervin, F; Du, X; Härkönen, A. International students in China: Education, student life and intercultural encounters: Springer, 2018.

Doerr, N. M; Taïeb, H. D. The romance of crossing borders: Studying and volunteering abroad: Berghahn Books, 2017. 


\section{movim nto \\ revista de educação do \\ programa de pós-graduação \\ faculdade de educação \\ ano 7 - número 15 - 2020}

Egekvist, U. E., Lyngdorf, N.-E., Du, X.-Y., \& Shi, J. (2016). Intercultural competence in host students? A study of Danish students facing China at home Intercultural Competence in Education (pp. 31-50): Springer, 2016.

Ennis, M. J., \& Riley, C. E. (2018). Practices in intercultural language teaching and learning: Cambridge Scholars Publishing, 2018.

Fong, J. (2020). An evaluation of an education abroad program on the intercultural learning and cross-cultural adaptability skills of university undergraduates. Higher Education Evaluation and Development,2020.

Forbes, H. D. (1997). Ethnic conflict: Commerce, culture, and the contact hypothesis: Yale University Press, 1997.

Foster, C. (2011). Intercultural Sensitivity in Foreign Student Advising: A Quantitative Analysis of Ethnocentrism within the Profession in the Post 9/11 Era. Journal of International Students 2011 Vol 1 Issue 2, 76, 2011.

Freed, B. F. (1995). Second language acquisition in a study abroad context (Vol. 9): John Benjamins Publishing, 1995.

Gaertner, S. L., Rust, M. C., Dovidio, J. F., \& Bachman, B. A. (1996). The contact hypothesis: The role of a common ingroup identity on reducing intergroup bias among majority and minority group members, 1996.

GarrettRucks, P. (2016). Intercultural competence in instructed language learning: Bridging theory and practice: IAP, 2016.

Gonçalves, S., \& Carpenter, M. A. (2013). Diversity, intercultural encounters, and education: Routledge, 2013.

Green, T. K. (2007). Discomfort at work: Workplace assimilation demands and the contact hypothesis. NCL Rev., 86, 379, 2007.

Gumperz, J. (2014). Intercultural encounters. The Discourse Studies Reader: Main Currents in Theory and Analysis, 217-224, 2014.

Hanson, R. A. (2017). Intergroup Contact through Study Abroad: An Investigation of Effects of Study Abroad on Student Engagement with Racial and Religious Diversity, 2017.

Hewstone, M. E., \& Brown, R. E. (1986). Contact and conflict in intergroup encounters: Basil Blackwell, 1986. 


\section{movim nto \\ revista de educação do \\ programa de pós-graduação \\ faculdade de educação \\ ano 7 - número 15 - 2020}

Ihlanfeldt, K. R., \& Scafidi, B. P. (2002). The neighbourhood contact hypothesis: Evidence from the multicity study of urban inequality. Urban Studies, 39(4), 619641, 2002.

Jackson, J. (2012). Education abroad The Routledge handbook of language and intercultural communication (pp. 456-470): Routledge, 2012.

Jackson, J. (2017). Intercultural Friendship. The international encyclopedia of intercultural communication, 1-9, 2017.

Jackson, J., \& Oguro, S. (2017). Intercultural interventions in study abroad: Routledge, 2017.

Kauffmann, N. L. (1992). Students Abroad: Strangers at Home. Education for a Global Society: ERIC, 1992.

Kern, R., \& Develotte, C. (2018). Screens and scenes: Multimodal communication in online intercultural encounters: Routledge, 2018.

Kiemele, J. (2009). Culturally proficient leadership: Intercultural sensitivity among elementary school principals: Arizona State University, 2009.

Kiliańska-Przybyło, G. (2017). The Anatomy of Intercultural Encounters. A CrossCultural Sociolinguistic Study: Wydawnictwo Uniwersytetu Śląskiego, 2017.

Klopf, D. W. (1998). Intercultural encounters: The fundamentals of intercultural communication: Morton Publishing Company Englewood, CO, 1988.

Kobayashi, A. (2009). An assessment of effects of the group process method of process work on the development of individuals' intercultural sensitivity: $A$ quantitative and qualitative analysis: Union Institute and University, 2009.

Komisarof, A., \& Hua, Z. (2015). Crossing boundaries and weaving intercultural work, life, and scholarship in globalizing universities: Routledge, 2015.

König, J. (2019). Developing intercultural sensitivity in a world of multicultural identities Moral and Spiritual Leadership in an Age of Plural Moralities (pp. 128-152): Routledge, 2019.

Korhonen, V. (2010a). Cross-cultural lifelong learning: University of Tampere, $2010 a$.

Korhonen, V. (2010b). Towards intercultural sensitivity-Some considerations when studying cross-cultural issues from a lifelong learning perspective. Cross-cultural lifelong learning, 13-38, 2010b. 


\section{movim nto \\ revista de educação do \\ programa de pós-graduação \\ faculdade de educação \\ ano 7 - número 15 - 2020}

Kriebernegg, U., Maierhofer, R., \& Penz, H. (2014). Intercultural encounters in education (Vol. 13): LIT Verlag Münster, 2014.

Kudo, K., Volet, S., \& Whitsed, C. (2017). Intercultural relationship development at university: A systematic literature review from an ecological and person-in-context perspective. Educational Research Review, 20, 99-116, 2017.

Kumar, S., Kumari, M., \& Alam, S. (2018). Ground realities and inhibitions in execution of MGNREGA in Jharkhand, India. Asian Journal of Research in Social Sciences and Humanities, 8(1), 74-93, 2018.

Kumari, M., \& Alam, S. (2017). झारखण्ड के कंवर आदिवासियों में स्वास्थ्य संबंधी अवधारणाएं एवं मानवजाति चिकित्सकीय प्रथाएं (Perceptions Related to Ailments and EthnoMedicinal Practices Among the Kawar Tribals of Jharkhand, India). Research Reinforcement, 5, 118-126, 2017.

Lai, C.-J. (2006). Sociocultural adaptation and intercultural sensitivity among international instructors of teaching English as a foreign language (TEFL) in universities and colleges in Taiwan: University of Minnesota MN, 2006.

Landis, D., Bennett, J., \& Bennett, M. (2003). Handbook of intercultural training: Sage Publications, 2003.

Lantz-Deaton, C. (2017). Internationalisation and the development of students' intercultural competence. Teaching in Higher Education, 22(5), 532-550, 2017.

Llanes, À., Cots Caimons, J. M., Mas-Alcolea, S., \& Aguilar Pérez, M. (2016). Studying the impact of academic mobility on intercultural competence: a mixedmethods perspective. Language learning journal, 2016, vol. 44, núm. 3, p. 304-322, 2016.

Lou, K. H. (2012). Student learning abroad: What our students are learning, what they're not, and what we can do about it. Ryūgaku, 14, 2011.

Mansouri, F., \& Vergani, M. (2018). Intercultural contact, knowledge of Islam, and prejudice against muslims in Australia. International journal of intercultural relations, 66, 85-94, 2018.

Mapes, J. (2020). Development of Intercultural Competence and Cultural Empathy in High School Students Participating in a Short-Term Study Abroad Exchange, 2020.

Maran, J., \& Stockhammer, P. (2013). Materiality and social practice: transformative capacities of intercultural encounters;[Conference Materiality and Practice- 


\section{movim nto \\ revista de educação do \\ programa de pós-graduação \\ faculdade de educação \\ ano 7 - número 15 - 2020}

Transformative Capacities of Intercultural Encounters; Internationales Wissenschaftsforum Heidelberg on March 25 to 27, 2010]: Oxbow, 2013.

Martin, J. N., \& Nakayama, T. K. (2013). Intercultural communication in contexts: McGraw-Hill New York, NY, 2013.

Matkin, G. S. (2005). Demographic similarity/difference, intercultural sensitivity, and leader-member exchange: A multilevel analysis: The University of NebraskaLincoln, 2005.

Meleady, R., Seger, C., \& Vermue, M. (2020). Evidence of a dynamic association between intergroup contact and intercultural competence. Group Processes \& Intergroup Relations, 2020 .

Meng, Q., Zhu, C., \& Cao, C. (2017). The role of intergroup contact and acculturation strategies in developing Chinese international students' global competence. Journal of Intercultural communlcatlon research, 46(3), 210-226, 2017.

Mickus, M., \& Bowen, D. (2017). Reducing the cultural divide among US and Mexican students through application of the contact hypothesis. Intercultural Education, 28(6), 496-507, 2017.

Miller, N. S., \& Brewer, M. B. (2013). Groups in contact: The psychology of desegregation: Academic Press, 2017.

Moore, A. S., \& Simon, S. (2015). Globally networked teaching in the humanities: Theories and practices: Routledge, 2017.

Nganga, R. W. (2006). Impact of cross-cultural interaction on counselor trainees' development of cultural empathy and intercultural sensitivity: University of Wyoming, 2006.

Nunez, C. (2007). Intercultural Sensitivity: Uitgeverij Van Gorcum, 2007.

Paluck, E. L., Green, S. A., \& Green, D. P. (2019). The contact hypothesis reevaluated. Behavioural Public Policy, 3(2), 129-158, 2019.

Peng, R.-Z., \& Wu, W.-P. (2016). Measuring intercultural contact and its effects on intercultural competence: A structural equation modeling approach. International journal of intercultural relations, 53, 16-27, 2016.

Pérez-Vidal, C. (2014). Language acquisition in study abroad and formal instruction contexts (Vol. 13): John Benjamins Publishing Company, 2014. 


\section{movim nto \\ revista de educação do \\ programa de pós-graduação \\ faculdade de educação \\ ano 7 - número 15 - 2020}

Petrovskaya, I., \& Shaposhnikov, S. (2020). Enhancing intercultural effectiveness in international virtual student teams: an exploratory study. Educational Research for Policy and Practice, 1-17, 2020.

Pettigrew, T. F. (1986). The intergroup contact hypothesis reconsidered, 1986.

Pettigrew, T. F., \& Tropp, L. R. (2005). Allport's intergroup contact hypothesis: Its history and influence. On the nature of prejudice: Fifty years after Allport, 262-277, 2005.

Plews, J. L., \& Misfeldt, K. (2018). Second language study abroad: Programming, pedagogy, and participant engagement: Springer, 2018.

Pochebut, L., \& Logashenko, Y. (2014). An intercultural sensitivity as a professional trait of specialists of humanitarian sphere. Paper presented at the Proceeding of the International Scientifical Conference May 23th-24th 2014.

Powers, S. (2018). Culturally Relevant Leisure Experiences as Predictors of Intercultural Sensitivity Among Study Abroad Students, 2018.

Ray, J. J. (1983). Racial attitudes and the contact hypothesis. The Journal of Social Psychology, 119(1), 3-10, 1983.

Ren, W. (2015). L2 pragmatic development in study abroad contexts: Peter Lang Bern, 2015.

Romanowski, P. (2017). Intercultural communicative competence in English language teaching in Polish state colleges: Cambridge Scholars Publishing, 2017.

Salisbury, M. H., An, B. P., \& Pascarella, E. T. (2013). The effect of study abroad on intercultural competence among undergraduate college students. Journal of Student Affairs Research and Practice, 50(1), 1-20, 2013.

Schauer, G. (2009). Interlanguage pragmatic development: The study abroad context: Bloomsbury Publishing, 2009.

Schiappa, E., Gregg, P. B., \& Hewes, D. E. (2005). The parasocial contact hypothesis. Communication monographs, 72(1), 92-115, 2005

Schwieter, J. W., Ferreira, A., \& Miller, P. C. (2018). Study abroad learners' metalinguistic and sociocultural reflections on short-and long-term international experiences. Intercultural Education, 29(2), 236-257, 2018.

Shook, N. J., \& Fazio, R. H. (2008). Interracial roommate relationships: An experimental field test of the contact hypothesis. Psychological Science, 19(7), 717723, 2008. 


\section{movim nto \\ revista de educação do \\ programa de pós-graduação \\ faculdade de educação \\ ano 7 - número 15 - 2020}

Silverman, D. (2013). Doing qualitative research: A practical handbook: SAGE publications limited, 2013.

Stephan, W. G. (1987). The contact hypothesis in intergroup relations, 2013.

Szabó, Á., Papp, Z. Z., \& Luu, L. A. N. (2020). Social contact configurations of international students at school and outside of school: Implications for acculturation orientations and psychological adjustment. International journal of intercultural relations, 77, 69-82, 2020.

Thomlison, T. D. (1991). Effects of a Study-Abroad Program on University Students: Toward a Predictive Theory of Intercultural Contact, 1991.

Ting-Toomey, S. (1999). Constructive intercultural conflict management. Communicating across cultures, 195-227, 1999.

Ting-Toomey, S. (2009). Intercultural conflict competence as a facet of intercultural competence development. The Sage handbook of intercultural competence, 100120, 2009.

Turner, J. (2010). Language in the academy: Cultural reflexivity and intercultural dynamics: Multilingual matters, 2010.

Van Binsbergen, W. M. (2003). Intercultural encounters: African and anthropological lessons towards a philosophy of interculturality (Vol. 4): LIT Verlag Münster, 2003.

Van Hook, C. W. (2000). Preparing Teachers for the Diverse Classroom: A Developmental Model of Intercultural Sensitivity, 2000.

Varela, O. E. (2017). Learning outcomes of study-abroad programs: A metaanalysis. Academy of Management Learning \& Education, 16(4), 531-561, 2017.

Vezzali, L., \& Stathi, S. (2016). Intergroup contact theory: Recent developments and future directions: Taylor \& Francis, 2016.

Walton, W. (2009). Internationalism, national identities, and study abroad: France and the United States, 1890-1970: Stanford University Press, 2009.

Wandel, R. (2003). Teaching India in the EFL-classroom: A cultural or an intercultural approach? Languages for intercultural communication and education, 6, 72-80, 2003.

Waßmuth, N., \& Edinger-Schons, L. M. (2018). Are people really strange when you're a stranger? A longitudinal study of the effect of intergroup contact on hostcountry identification. International journal of intercultural relations, 67, 58-70, 2018. 


\section{movim nto \\ revista de educação do \\ programa de pós-graduação \\ faculdade de educação \\ ano 7 - número 15 - 2020}

Werth, J. L., \& Lord, C. G. (1992). Previous conceptions of the typical group member and the contact hypothesis. Basic and Applied Social Psychology, 13(3), 351-369, 1992.

West, L. C. (2009). Evaluating the intercultural sensitivity scale with counselors in international schools: Regent University, 2009.

Whalen, B. (2015). Assessing study abroad: Theory, tools and practice: Stylus Publishing, LLC, 2015.

Wilkinson, L. C. (2007). A developmental approach to uses of moving pictures in intercultural education. International journal of intercultural relations, 31(1), 1-27, 2007.

Winkelman, M. (2005). Cultural awareness, sensitivity and competence: Eddie Bowers Pub, 2005.

Winkler, D. W., \& Tang, L. (2009). Hidden Treasures and Intercultural Encounters. 2. Auflage: Studies on East Syriac Christianity in China and Central Asia (Vol. 1): LIT Verlag Münster, 2009.

Yuen, C. Y., \& Grossman, D. L. (2009). The intercultural sensitivity of student teachers in three cities. Compare, 39(3), 349-365, 2009.

Zhou, S., Page-Gould, E., Aron, A., Moyer, A., \& Hewstone, M. (2019). The extended contact hypothesis: A meta-analysis on 20 years of research. Personality and Social Psychology Review, 23(2), 132-160, 2019.

\section{ABOUT THE AUTHOR}

ASHRAF ALAM holds master's in Education (M.Ed.), M.Sc. in Mathematics, M.A. in Public Administration, B.Sc. (Hons.) in Computer Science, Bachelor's degree in Education (B.Ed.), PG Diploma in Higher Education (PGDHE), PG Diploma in Computer Applications (PGDCA), Certificate Programme in Value Education (CPVE), PG Diploma in Criminology and Police Administration (PGDC\&PA), Certificate in Guidance (CIG), and PG Diploma in Educational Technology.

E-mail: ashraf_alam@live.com 